\title{
BENEFICIAL EFFECTS OF ETHANOLIC LEAF EXTRACT OF CORIANDRUM SATIVUM ON METANIL YELLOW INDUCED ALTERATION INACTIVITY OF CATALASE AND LEVEL OF LIPID PEROXIDATION IN HERCINE CARDIAC TISSUE IN VITRO
}

\author{
RABINDRA NATH DOME ${ }^{1}$, SANJIB HAZRA ${ }^{1}$, DEBOSREE GHOSH², SUVENDU GHOSH ${ }^{*}$
}

1Department of Physiology, Hooghly Mohsin College, P. O. Chinsura, Dist-Hooghly, Pin 712101, West Bengal, India, ${ }^{2}$ Department of Physiology, Government General Degree College, Kharagpur II, P. O.-Madpur Dist-Paschim Medinipur, Pin: 721149, West Bengal, India Email: dr.suvendughosh@rediffmail.com

Received: 28 Jan 2017 Revised and Accepted: 31 Mar 2017

\begin{abstract}
Objective: The primary aim of the study was to find out a suitable effective dose of metanil yellow that can cause alterations of lipid peroxidation and catalase activity in the heart in vitro and to determine the effectiveness of graded doses of Coriandrum sativum as an antioxidant in preventing lipid peroxidative damage to cardiac tissue and back up catalase activity.

Methods: Metanil yellow at different doses $(10,25,35,50 \mu$ in phosphate buffer) were applied on isolated hircine heart homogenate (10\%) in in vitro followed by estimation of lipid peroxidation and catalase activity after completion of the incubation period. Another set of the experiment included incubation of the heart homogenates with graded dilutions of ethanolic leaf extracts of Coriandrum sativum (CsEth) at concentrations of 10, $20,30,40 \mu \mathrm{l}$ in phosphate buffer medium followed by quantification of the same biochemical parameters as above. This was followed by coadministration of the selected effective dose of metanil yellow (35 $\mu \mathrm{l})$ and ethanolic leaf extract of Coriandrum sativum (30 $\mu \mathrm{l})$ on heart homogenate to track the variation in lipid peroxidation and catalase activity in heart homogenate in vitro.
\end{abstract}

Results: Metanil yellow significantly lowered catalase activity in isolated cardiac tissue that was reflected in elevated lipid peroxidation assuming free radical induced oxidative injury to cardiac tissue $(\mathrm{p}<0.01)$. However ethanolic leaf extract of Cordiandrum sativum buffered such changes $(\mathrm{p}<0.01)$ significantly, presuming a protective action against oxidative cardiac damage.

Conclusion: It may be concluded that ethanolic leaf extract of Coriandrum sativum is a promising cardioprotective remedy not only in mitigating free radical mediated lipid peroxidative damage to cardiac tissue but also in reinstating normal catalase activity that may be used an unique herbal based remedy for such cardiac ailments in future.

Keywords: Cardioprotection, Coriandrum sativum, Metanil yellow, Methanolic leaf extract, Myocardial infarction

(C) 2017 The Authors. Published by Innovare Academic Sciences Pvt Ltd. This is an open access article under the CC BY license (http://creativecommons.org/licenses/by/4.0/) DOI: http://dx.doi.org/10.22159/ijpps.2017v9i5.17331

\section{INTRODUCTION}

Reactive oxygen species (ROS) are an important group of molecules that are generated usually by oxygen slippage either during mitochondrial electron transport or extra-mitochondrial electron transport systems [1]. An imbalance between the generation of such free radicals and scavenging activity of these free radical by cellular antioxidant enzyme cascade may be a cause for generation of oxidative stress. Oxidative stress may be the etiology of a multitude of ailments ranging from neurological, haematological, immunological, cardiovascular, and genetic to developmental disorders [2].

Mammalian heart is highly aerobic and oxygen demanding organ. In addition, cardiac tissue is normally dynamic with highly metabolic demand and mitochondrial rich myocardial work out may be a source of oxygen slippage turning out as oxidative injury to the heart. ROS generation in the heart may affect normal myocardial contractility induce maladaptive myocardial remodelling and subsequently, heart failure may be an outcome [3].

Cellular antioxidant mechanisms work in cascade in the heart to combat the stress mediated cardiac injury. Formerly superoxide anion generation are prevented by vitamin $\mathrm{E}$, formation of hydrogen peroxides from superoxide radicals are again checked by sulphur containing amino acids like cysteine and methionine, and later generation of hydroxyl radicals are counteracted by coordinated actions by superoxide dismutase and catalase which otherwise may interact with polyphenolic lipids to form lipid hydroxides, a product of lipid peroxidation. Although SOD and glutathione peroxidase are adequate in cardiac tissue to combat oxidative damage, catalase is very crucial for $\mathrm{H}_{2} \mathrm{O}_{2}$ detoxification in cardiac myocytes [4].
Amongst the spectrum of sources for free radical mediated oxidative stress, changing lifestyle pattern nowadays may be a good booster of oxidative stress induced systemic disorders [5]. Eye attracting coloured foods consumption in our country like roadside cheap and hotel made biriyani, mango and milk shakes, cheese and sweets, ladoos has become a common fashion amongst inhabitants belonging to low and medium socio-economic status in metropolitan cities. Such foods are generally adulterated with metanil yellow (as observed from our laboratory studies) [6]. Consumption of such food adulterant may alter a metabolic pattern that may account for the generation of free radicals leading to oxidative stress [7].

Antioxidant supplementation is widely followed the regime to combat cellular oxidative insult. Amongst these groups, synthetic antioxidant supplantation has been criticized my many and shifting of therapy towards the use of indigenous plant-based chemicals (including polyphenols, flavonoids, phenolic acids, tannins etc.) is recently gaining recognition [8].

One such plant widely used by Indians in diet, popular for its delicious tastemaker is the annual herb, Coriandrum sativum.

Apart from raw consumption of its leaves, seeds of this plant are also used as common Indian spice. Essential oils extracted from leaves, seeds, fruits etc. is used as folk medicine for curing bacterial, fungal diseases and antioxidant therapy [9]. Coriandrum leaves have been reported to have antidiabetic, anti ulcer, anti-arthritic and several other medicinal uses [10]. Studies showed that Coriandrum leaves extract has anticancer activity [11]. Studies also showed that reversal of memory deficit in mice model is possible using Coriandrum leaves extract [12]. Coriandrum sativum leaves extract has been found to have radical scavenging potential and it has the 
ability to protect DNA damage [13]. Coriandrum sativum leaves extract has been reported to scavenge DPPH and has antibacterial [14]. Our earlier studies reveal that methanolic extract of the leaves of Coriandrum sativum has hepatoprotective effect in vitro [5]. However cardioprotective effects of ethanolic leaf extract of this plant is yet to be scrupulously determined.

One of the principal aims of this study was to explore the possible effects of metanil yellow on $\mathrm{H}_{2} \mathrm{O}_{2}$ metabolism by monitoring catalase activity which may partially anticipate the mechanism of activation of lipid peroxidation in cardiac tissue in vitro. The secondary aspect of this study was to find out an effective dose of this drug in producing such oxidative insult.

\section{MATERIALS AND METHODS}

\section{Collection of Coriandrum sativum plant}

The shoots of Coriandrum sativum were collected from the local market. Plant along with its seeds was collected from Chinsurah Hooghly, West Bengal, herbarium was prepared and the specimen was identified by a concerned expert from the Botanical Survey of India, Central National Herbarium as Coriandrum sativum [Specimen voucher number is HMC/SG/PHYSIO-02].

\section{Processing of the leaves}

Fresh leaves were isolated from the plant, washed and dried on filter paper at normal room temperature. The dried leaves were weighed. The leaves were then placed in a hot air oven maintained at $50{ }^{\circ} \mathrm{C}$ until they became crispy and dry. The dried leaves were then grinded in mortar and pastel to dry powder. The powder was then stored in air tight sealed container until further use. For ethanolic extract formation, $0.1 \mathrm{~g}$ dried powder was dissolved in $20 \mathrm{ml}$ of ethanol and kept for 30 min which was then filtered. This process of extraction was practiced freshly for each study.

\section{Physical examination}

The colour and constituency of the dried powder were monitored regularly. $\mathrm{pH}$ of the ethanolic leaf extract was determined using a digital $\mathrm{pH}$ meter before use by measuring the $\mathrm{pH}$ of a standard buffer solution of $\mathrm{pH} 9$ and another of $\mathrm{pH} 3$ respectively.

Relative moisture content was measured by the following protocol:

Fresh weight (FW) of the leaves was measured followed by placement in $9 \mathrm{~cm}$ Petri dish containing distilled water; maintained as such for $24 \mathrm{~h}$ at $4{ }^{\circ} \mathrm{C}$ in the dark. The leaves were then blotted dry and the turgor fresh weight (TW) was determined. Subsequently, the leaves were dried at $70^{\circ} \mathrm{C}$ for $24 \mathrm{~h}$. Finally, the dry weight (DW) was measured [Barr HD]. The relative water content was finally calculated by using the equation:

$$
R W C(\%)=[(W-D W) /(T W-D W)] \times 100
$$

Where,

W-sample fresh weight

TW-sample turgid weight

DW-sample dry weight

\section{Chemical examination (Qualitative screening)}

Saponin content of the leaves extract were estimated by the methods of Kuganathan et al. 2008 and Srivastava et al., 2010. [16, 17], tannins and phenols content of the leaves extract were estimated by the method of Srivastava et al., 2010 [17], alkaloids content of the leaves extract were estimated by using Mayer's, Dragendroff's, Hager's and Wagner's reagents, gum and mucilage and flavonoids content of the leaves extract were estimated by the method of Srivastava et al., 2010 [17].

\section{Metanil yellow solution preparation (MY)}

$1 \mathrm{mg}$ metanil yellow (Sigma brand) was dissolved in distilled water at $1: 1$ (weight/volume, i. e, $1 \mathrm{mg} / \mathrm{ml}$ ).

\section{Procuration of goat heart}

Goat heart was collected from local shops immediately after slaughtering; parcelled in ice container and stored in laboratory at$20^{\circ} \mathrm{C}$ for future use $(\mathrm{n}=8)$.

\section{Preparation of tissue homogenate}

A 10\% tissue homogenate of heart was prepared (mostly with the fresh tissues) in ice cold 0.1M phosphate buffer (ph 7.4) using a Potter-Elvehjem homogenizer. The homogenates prepared were used for further in vitro studies.

\section{In vitro studies}

Isolated heart homogenates were incubated in a graded concentration of Metanil Yellow (MY) in the following series 10, 25, $35,50 \mu \mathrm{l}$ in phosphate buffer medium. Another set of experiments included incubation of the heart homogenates with graded dilutions of ethanolic leaf extracts of Coriandrum sativum (CsEth) at concentrations of $10,20,30,40 \mu \mathrm{l}$ in phosphate buffer medium. A subsequent series of experiment was carried out co-incubation of heart homogenate with selected dose of MY and above mentioned concentrations of CsEth. The final set of incubation included homogenate incubation with selected dose of MY, selected dose of CsEth and co-incubation of selected dose of CsEth and MY in phosphate buffer solution. Control solution for all experiments included $10 \%$ heart homogenate in phosphate buffer solution. The incubation period for al sets of experiments included a $30 \mathrm{~min}$ duration at $37^{\circ} \mathrm{C}[18,19]$.

\section{Biochemical analysis \\ Lipid peroxidation}

The level of lipid peroxidation in heart tissue of goat was estimated by the method of Buege and Aust with modifications $[5,20]$.

\section{Catalase activity}

The activity of catalase enzyme was estimated by the method of Beer and Seizer 1952 [21] and as modified by Mitra et al. 2012 [22].

\section{Protein estimation}

The protein content of cardiac tissue was estimated by the method of Lowry [23].

\section{RESULTS}

Phytocomponents like saponins, tannins and phenols, gum and mucilage and flavonoids etc. were qualitatively estimated by using standardized protocols. We found that except saponin all three other constituents were present in the ethanolic extract of Coriandrum sativum (table 1 ).

Table 1: Qualitative analysis of the phytoconstituents of ethanolic leaves extract of Coriandrum sativum

\begin{tabular}{lll}
\hline Qualitative test & Method Used & Results \\
\hline Saponins & Foam method & - \\
Tannins and Phenols & Ferric chloride method & + \\
Gum and Mucilage & Alcohol method & + \\
Flavonoids & Sodium hydroxide method & + \\
\hline
\end{tabular}

+: Present, -: Absent

Qualitative analysis of the phytoconstituents of ethanolic leaves extracts of Coriandrum sativum revealed the presence of tannins and phenols, gum and mucilage and flavonoids. Saponin was found to be absent.

Our studies reveals that there was no significant alteration in the level of lipid peroxidation or activity of the antioxidant enzyme, catalase in goat heart when the tissues were treated in vitro with various doses of Coriandrum sativum $(10 \mu \mathrm{l}, 20 \mu \mathrm{l}, 30 \mu \mathrm{l}, 40 \mu \mathrm{l}, 50 \mu \mathrm{l})$ [table 2.]. 
Table 2: Effect of various doses of ethanolic extract of Coriandrum sativum on the level of lipid peroxidation and catalase activity of goat heart

\begin{tabular}{|c|c|c|c|c|c|c|}
\hline Parameters & Control & CsEth 10 & CsEth 20 & CsEth 30 & CsEth 40 & CsEth 50 \\
\hline $\begin{array}{l}\text { Level of lipid peroxidation [nmoles of } \\
\text { TBARS per mg protein] }\end{array}$ & $13.97 \pm 1.0234$ & $13.78 \pm 1.0432$ & $14.18 \pm 1.0232$ & $13.71 \pm 1.0487$ & $14.01 \pm 1.0384$ & $14.14 \pm 1.0329$ \\
\hline $\begin{array}{l}\text { Catalase activity [ } \mu \text { moles of } \mathrm{H}_{2} \mathrm{O}_{2} \\
\text { consumed per minute per mg protein ] }\end{array}$ & $60.54 \pm 0.4942$ & $61.55 \pm 0.15899$ & $62.34 \pm 0.2127$ & $62.55 \pm 0.3150$ & $62.60 \pm 0.1159$ & $62.76 \pm 0.1822$ \\
\hline
\end{tabular}

$n=6$, Values are mean $+S E$

Our studies reveal that increasing doses of metanil yellow caused an increase in the level of lipid peroxidation in a dose-response manner in goat heart in vitro. Metanil yellow at a dose of $35 \mu \mathrm{l}$ (concentration: $1 \mathrm{mg} / \mathrm{ml}$ ) caused a significant increase in the level of lipid peroxidation in goat heart in vitro compared to that of control $(\mathrm{P}<0.01$ Vs. Control) [fig. 1.].

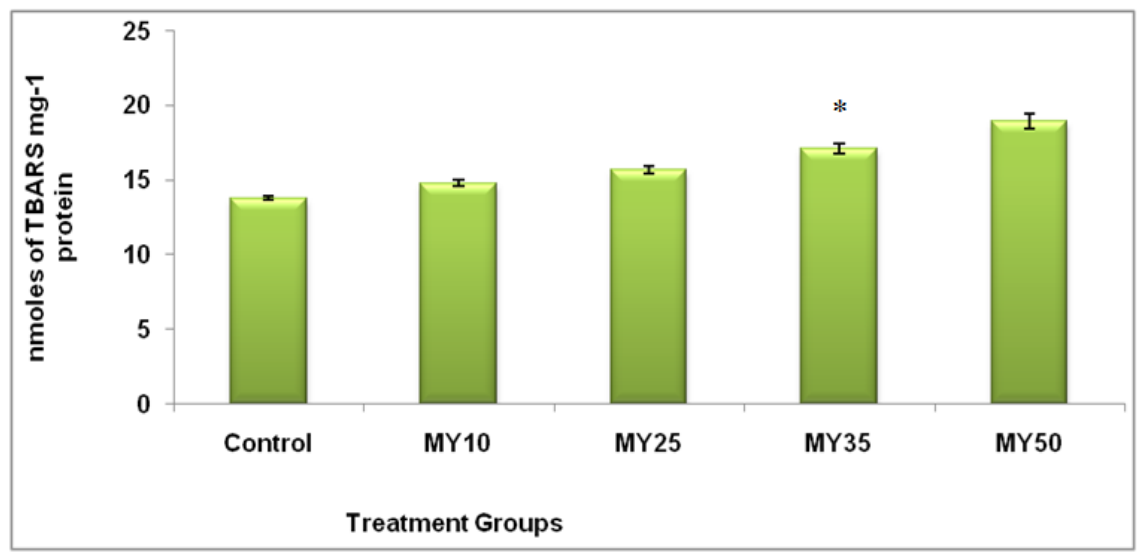

Fig. 1: Effects of various doses of metanil yellow on lipid peroxidation level in heart tissue of goat ( $n=6)$; Values are mean+SE, *P<0.01 Vs. control

Our studies reveal that increasing doses of metanil yellow caused a gradual decrease in the activity of catalase in a dose-response manner in goat heart in vitro. Metanil yellow at a dose of $35 \mu \mathrm{l}$ (concentration: $1 \mathrm{mg} / \mathrm{ml}$ ) (MY35) caused a significant decrease in the activity of catalase in goat heart in vitro compared to that of control $(* \mathrm{P}<0.01$ Vs. Control) [fig. 2.]. We used the dose of $35 \mu \mathrm{l}$ (concentration: $1 \mathrm{mg} / \mathrm{ml}$ ) of metanil yellow for the rest of our study.

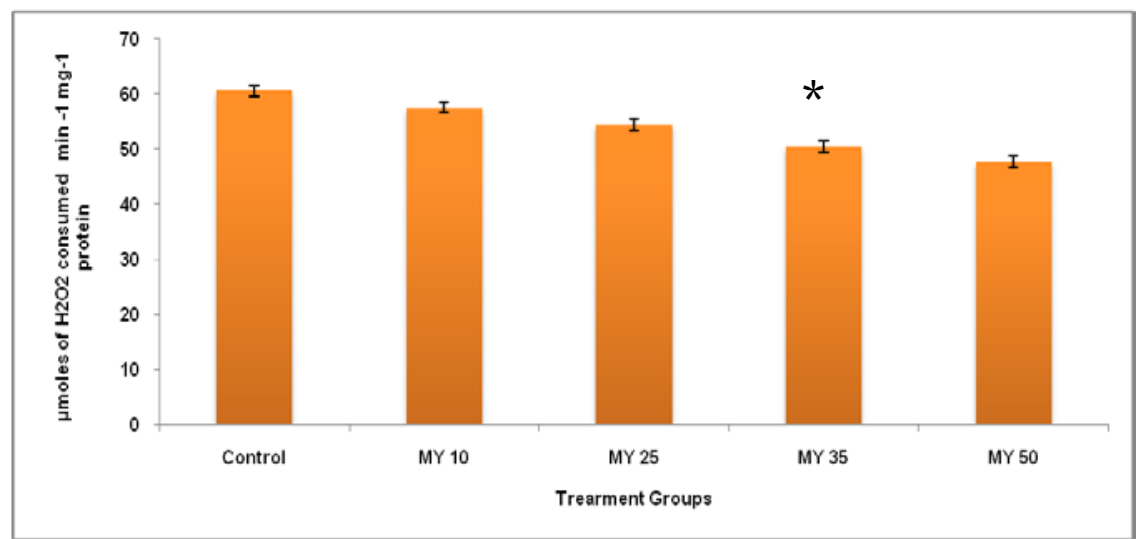

Fig. 2: Effects of various doses of metanil yellow on catalase activity in heart tissue of goat (n=6); Values are mean+SE; *P<0.01 Vs. control

Our studies reveal that metanil yellow at a dose of $35 \mu \mathrm{l}$ (concentration: $1 \mathrm{mg} / \mathrm{ml}$ ) caused a significant increase in the level of lipid peroxidation compared to that of control in goat heart in vitro. Metanil yellowat a dose of $35 \mu$ l (MY35) caused a significant decrease in the activity of catalase in goat heart in vitro compared to that of control $(* \mathrm{P}<0.01$ Vs. Control) [fig. 3].

We found that co-treatment of heart tissues of goat in vitro ethanolic extract of Coriandrum sativum (EthCs)at various doses $(10 \mu \mathrm{l}, 20 \mu \mathrm{l}$, $30 \mu \mathrm{l}, 40 \mu \mathrm{l}, 50 \mu \mathrm{l}$ ) protected the level of lipid peroxidation in goat heart from being increased in a dose response manner compared to that of metanil yellow treated heart. Our studies further reveal that co-treatment of goat heart tissue with ethanolic extract of Coriandrum sativum at the dose of $30 \mu \mathrm{l}$ protected the level of lipid peroxidation from being increased in the cardiac tissue mediated by metanil yellow exposure at the dose of $35 \mu \mathrm{l}$ (MY35) (concentration: $1 \mathrm{mg} / \mathrm{ml}$ ).

The level of lipid peroxidation in the $35 \mu \mathrm{l}$ (concentration: $1 \mathrm{mg} / \mathrm{ml}$ ) metanil yellow and $30 \mu \mathrm{l}$ ethanolic extract of Coriandrum sativum (MY35+EthCs30) co-treated tissue was found to be significantly lowered than that of metanil yellow exposed tissue (MY35) $(* * \mathrm{P}<0.01)$ [fig. 3,5$]$. 


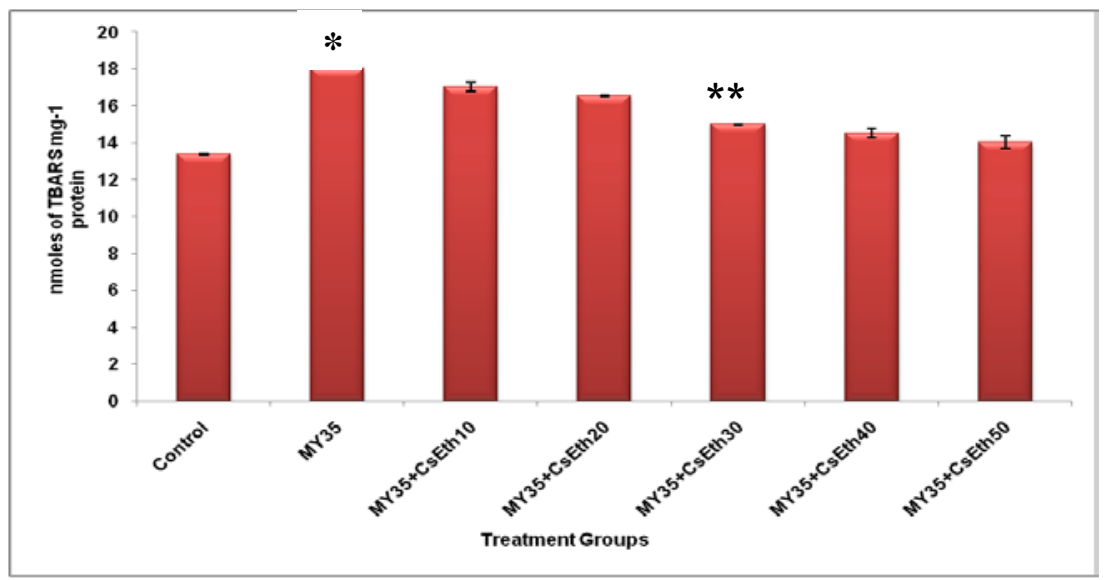

Fig. 3: Dose-response study of ethanolic leaves extract of Coriandrum sativum against metanil yellow induced lipid peroxidation in heart tissue of goat; $(\mathrm{n}=6)$; values are mean+SE; ${ }^{*} \mathrm{P}<0.01$ Vs control; ${ }^{*} \mathrm{P}<0.01$ Vs MY35 [metanil yellow at a dose of $35 \mu \mathrm{l}$ (MY35) (concentration: $1 \mathrm{mg} / \mathrm{ml}$ )]

Our studies reveal that metanil yellow at a dose of $35 \mu \mathrm{l}$ (concentration: $1 \mathrm{mg} / \mathrm{ml}$ ) caused a significant decrease in the activity of catalase enzyme in heart tissue of goat $(n=6$ each) compared to that of control. We found that co-treatment of heart tissues of goat in vitro ethanolic extract of Coriandrum sativum (EthCs)at various doses $(10 \mu \mathrm{l}, 20 \mu \mathrm{l}, 30 \mu \mathrm{l}, 40 \mu \mathrm{l}, 50 \mu \mathrm{l})$ protected the activity of catalase enzyme in goat heart from being increased in a dose response manner compared to that of metanil yellow treated heart. Our studies further reveal that co-treatment of goat heart tissue with ethanolic extract of Coriandrum sativum at the dose of 30 $\mu \mathrm{l}$ protected the activity of catalase enzyme from being decreased in the cardiac tissue mediated by metanil yellow exposure at the dose of $35 \mu \mathrm{l}$ (concentration: $1 \mathrm{mg} / \mathrm{ml}$ ).

The activity of catalase enzyme in the $35 \mu$ (concentration: 1 $\mathrm{mg} / \mathrm{ml}$ ) metanil yellow and $30 \mu \mathrm{l}$ ethanolic extract of Coriandrum sativum (MY35+EthCs30) co-treated tissue was found to be significantly higher than that of metanil yellow exposed tissue (MY35) $\left({ }^{* *} \mathrm{P}<0.01\right)$ [fig. 4, 6].

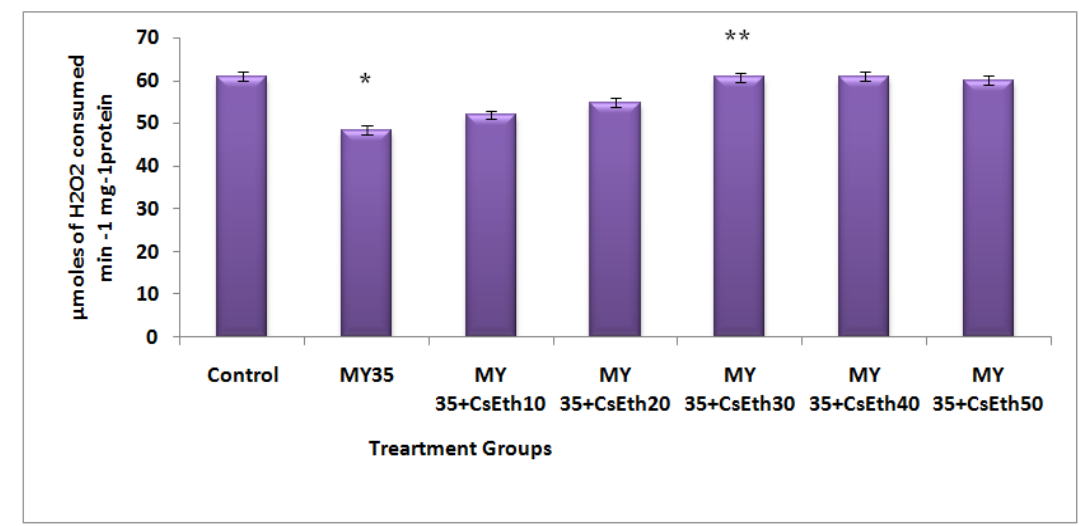

Fig. 4: Dose response study of ethanolic leaves extract of Coriandrum sativum against metanil yellow induced changes in the activity of catalase enzyme in heart tissue of goat $(\mathrm{n}=6)$. Values are mean+SE; ${ }^{*} \mathrm{P}<0.01$ Vs Control; $* * \mathbf{P}<0.01$ Vs MY35 [metanil yellow at a dose of 35 $\mu \mathrm{l}$ (MY35) (concentration: $1 \mathrm{mg} / \mathrm{ml}$ )]

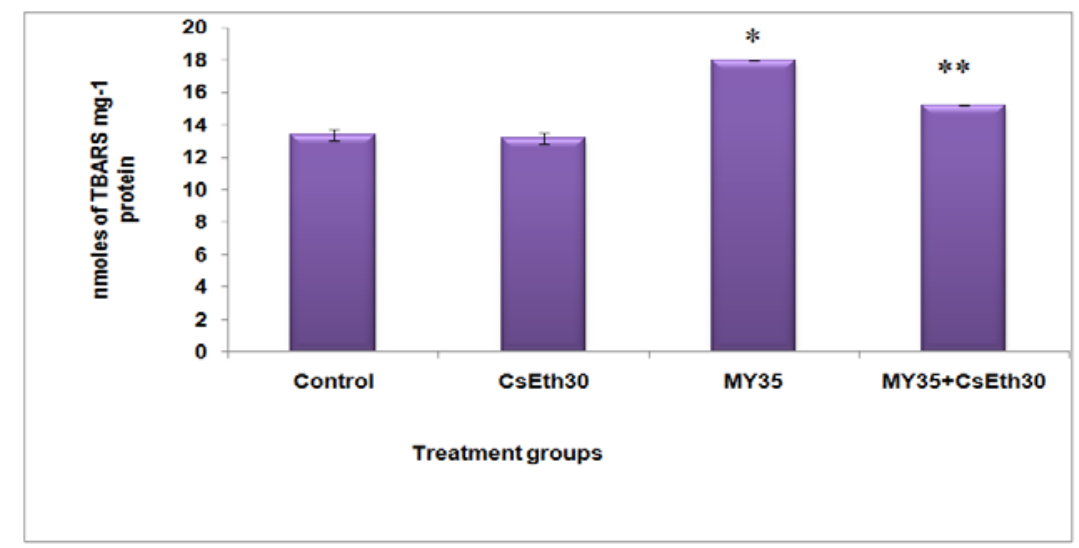

Fig. 5: Protective effect of ethanolic leaves extract of Coriandrum sativum against Metanil yellow induced changes in the level of lipid peroxidation in hearts of goat $(n=6)$ values are mean+SE; ${ }^{*} P<0.01$ Vs Control; ${ }^{*} * \mathbf{P}<0.01$ Vs MY35 [metanil yellow at a dose of $35 \mu$ l (MY35) (concentration: $1 \mathrm{mg} / \mathrm{ml}$ )] 


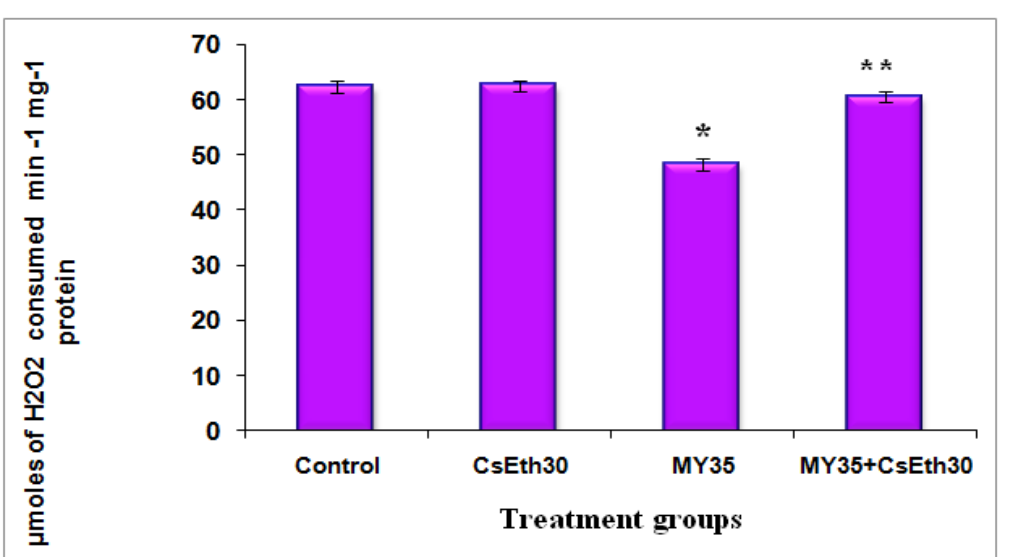

Fig. 6: Effect of effective dose of ethanolic leaves extract of Coriandrum sativum on effective dose of Metanil yellow on activity of catalase in hearts of goat $(n=6)$; values are mean+SE; ${ }^{*} \mathrm{P}<0.01$ Vs Control; ${ }^{*} \mathrm{P}<0.01$ Vs MY35 [metanil yellow at a dose of $35 \mu \mathrm{l}$ (MY35) (concentration: $1 \mathrm{mg} / \mathrm{ml}$ )]

\section{DISCUSSION}

Catalase is a conjugative homotetrameric enzyme having $\mathrm{Fe}^{3+}$ centred heme group. It has a molecular weight of $64 \mathrm{kDa}$. Eukaryotic ezyme having both catalase and peroxidase activity. It is one of the chief subcellular antioxidant defence enzyme with the highest activity in liver and erythrocytes, followed by kidney and adipocytes, moderate in lungs and pancreas and least in brain and heart. It is one of the key detoxifier of $\mathrm{H}_{2} \mathrm{O}_{2}$ converting the former into water and oxygen. It scavenges about $80 \%$ of $\mathrm{H}_{2} \mathrm{O}_{2}$ in cardiac myocytes yet its overall activity is low. This may partially account for the high sensitivity of the heart to oxidative insult [24]. Studies revealed that in ischemia-reperfusion injury, subsequent supplementation of catalase in perfusion fluid can efficiently detoxify $\mathrm{H}_{2} \mathrm{O}_{2}$ in the isolated heart [25].

Heavy metals induced cardiac toxicity is known to reduce catalase activity significantly [26]. Metanil yellow, when administered in single dose parenterally, induces P-450 and its dependent monooxygenases which is related it's to hepatic metabolism and toxicity [27]. P-450 dependent monooxygenase is also adequate in the heart. This heme-thiolate enzyme is involved in the metabolism of environmentally toxic chemicals and endogenous substrates through oxidative, peroxidative and reductive changes and some of the subfamily of enzymes may be detrimental to cardiac function as it may induce the generation of ROS [28]. Metanil yellow exposure to isolated heart perhaps by some likely mechanism induces ROS production in the heart. A significant reduction in catalase activity in isolated goat heart exposed to metanil yellow in vitro may be attributed to excess free radical generation by metanil yellow [5] analogous to acute myocardial infarction which is a consequence of an excess of $\mathrm{H}_{2} \mathrm{O}_{2}$ and superoxide production resulting in decreased activity of catalase [29].

LPO activity in the metanil yellow exposed isolated hearts was observed to be significantly enhanced. LPO is approximated by the accumulation of malonic dialdehyde [30]. There occurs a spectrum of cellular alterations including membrane phospholipid peroxidation, thiol oxidation, utilization of major chain-breaking membrane anti-per oxidants. Further oxidative alterations of myocardial membrane polyunsaturated fatty acids are related to increased level of lipid peroxidation which may be a probable manifestation of progression of myocardial infarction [31].

Amongst the various mechanisms involved in free radical induced lipid peroxidation followed by myocardial ischaemia, a deterioration of antioxidant system in the myocardium is suggested [32]. In the present study, increased lipid peroxidation may be attributed to decreased catalase activity since the available literature described catalase as a significant enzyme in cardiac myocytes in terms of its low content but highest activity in scavenging hydrogen peroxides which otherwise generates lipid peroxides and lipid hydroperoxides.
The findings of the present work also suggest that metanil yellow is cardiotoxic and may be an inducer of myocardial infarction mediated through oxidative stress.

Cardioprotection by phytochemicals or herbal medicine is widely accepted trend and is already in use recently. Many plants are known to be a good source of carotenoids, triterpenes, flavonoids, and alkaloids that are potent to combat free radical mediated cardiac toxicity including myocardial infarction and ischemic heart diseases [33]. Some of such commonly listed plants are Terminalia arjuna, Andrographis paniculate, Citrus aurantium, Vitis Vinifera, Cocos nucifera, Zingiber officinale, Allium cepa, Curcuma longa, Terminalia chebula, Azadirachta indica etc and many others [32] Coriandrum sativum, however, is not enlisted. Our observations showed that ethanolic leaf extract of Coriandrum has a good potential to counteract metanil yellow lipid peroxidative damage to cardiac tissue and restoring the normal activity of catalase. It has already been admitted that plants containing tannins, polyphenols and flavonoids have cardioprotective action [34]. Of the various phytoconstituents, qualitative estimation of ethanolic leaf extract of Coriandrum has shown the presence of a spectrum of compounds having antioxidant potential. Amongst such compounds phenols have been established as a good inhibitor of lipid peroxidation in in vitro studies [35]. Polyphenols and tannins are competent metal chelators and their high redox potentials bestow them with free radical quenching and hydrogen donating potential [36]. Flavonoids and tannins can also check superoxide radical generation [37]. Further, it has been reported that flavonoid content in tea leaf extract may be accountable for the decrease in lipid peroxidation and restoration of catalase activity in cadmium-induced oxidatively stressed rats [38]. The observations of the present study mimic such similar findings and it may be thus summated phenolic constituents, flavonoids and tannins present in Coriandrum leaves may be good detoxifiers of free radical mediated peroxidative damage in goat heat exposed to metanil yellow and efficiently refurbish normal catalase activity in the heart.

\section{CONCLUSION}

Thus it may be concluded that altered metabolic pattern induced by metanil yellow in the isolated hircine heart may induce cardiotoxicity by the generation of ROS which includes superoxide anion radical followed by spawning of excess hyrodrogen peroxide that impinges normal catalase activity subsequently leading to peroxidative damage to lipids of isolated heart in vitro. Ethanolic leaf extract of Coriandrum sativum may alleviate such free radical mediated cardiotoxicity because of the presence of indigenous phytochemicals like tannins, flavonoids and phenols that quench the free radicals with the beneficiary effect of restoring catalase activity in in vitro. Thus the study may indicate that the leaf extract of this plant might be promising in the development of new drugs to treat various diseases including cardiac ailments. 


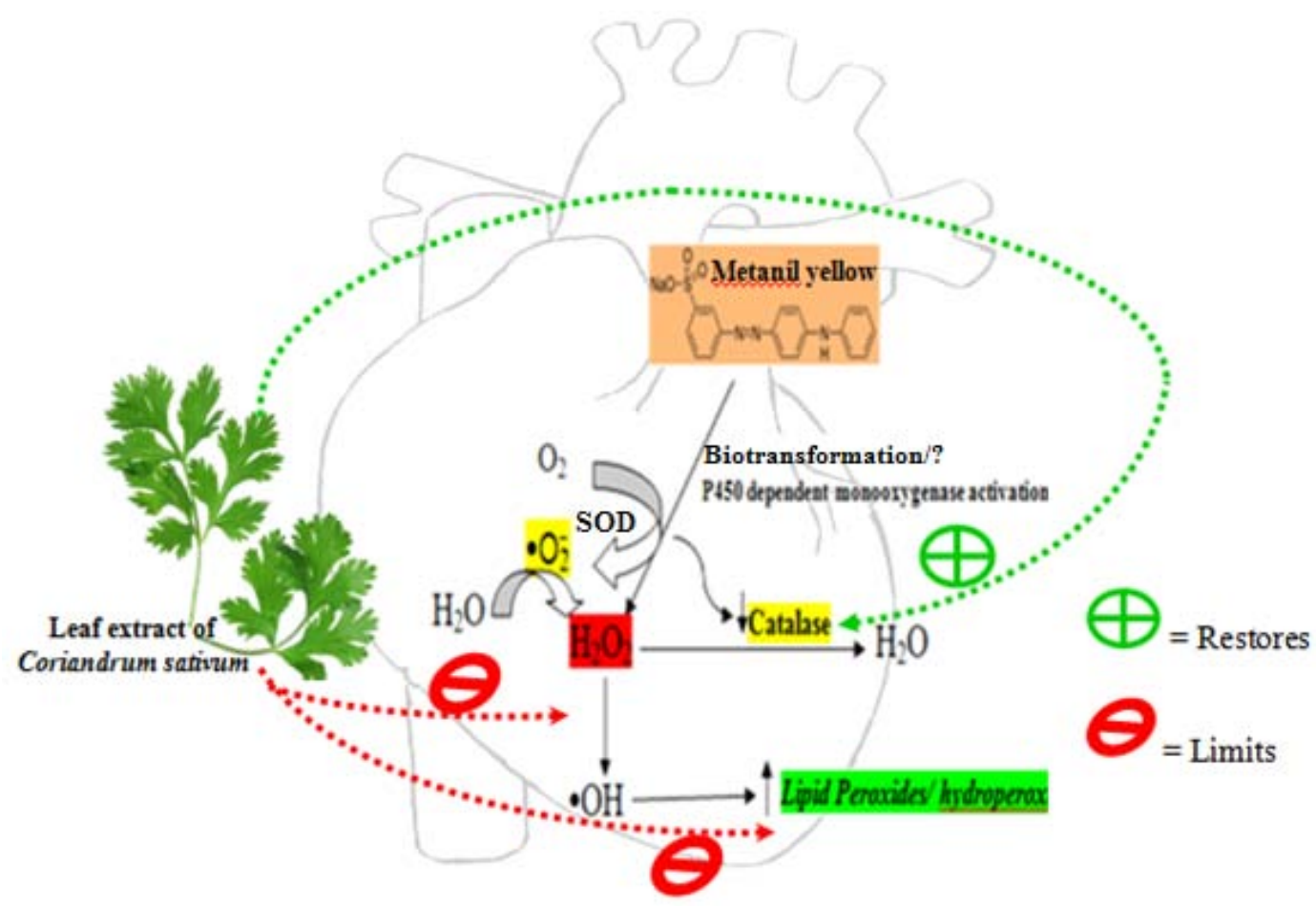

Scheme 1: Mechanism of amelioration of metanil yellow induced cardiotoxicity by ethanolic leaf extract of Coriandrum sativum in goat heart

\section{ACKNOWLEDGEMENT}

RND, SH and Dr. SG acknowledge the Department of Physiology, Hooghly Mohsin College and Dr. DG acknowledges the Department of Physiology, Government General Degree College, Kharagpur II.

Dr. SG and Dr. DG designed and conceived the study and analyzed the findings and together composed the manuscript. RND and SH performed the experiments and calculated and arranged the data. Finally, all authors read and approved the manuscript.

\section{CONFLICT OF INTERESTS}

Declared none

\section{REFERENCES}

1. Patel SP, Katyare SS. A comparative study of reactive oxygen species (ros) related parameters in rat tissues. Indian J Clin Biochem 2006;21:48-53.

2. Raman K, Rajni S. Review on rasayana and its relevance in the current scenario. Punarnav 2014;2:1-10.

3. Tsutsui H, Kinugawa S, Matsushima S. Oxidative stress and heart failure. Am J Physiol Heart Circ Physiol 2011;301:H2181-90.

4. Thayer WS. Role of catalase in the metabolism of hydrogen peroxide by the perfused rat heart. FEBS Lett 1986;202:137-40.

5. Hazra S, Dome R, Ghosh S, Ghosh D. Protective effect of methanolic leaves extract of coriandrum sativum against metanil yellow induced lipid peroxidation in goat liver: an in vitro study. Int J Pharmacol Pharm Sci 2016;3:34-41.

6. Gupta S, Sundarrajan M, Rao KV. Tumor promotion by metanil yellow and malachite green during rat hepatocarcinogenesis is associated with dysregulated expression of cell cycle regulatory proteins. Teratog Carcinog Mutagen 2003; Suppl 1:301-12.

7. Al-Malki AL, Sayed AAR. Bees' honey attenuation of metanilyellow-induced hepatotoxicity in rats. J Evidence-Based Complementary Altern Med 2013. http://dx.doi.org/10.1155/ 2013/614580.

8. Saha MR, Hasana SMR, Aktera R, Hossaina MM, Alam MS, Alam $\mathrm{MA}$, et al. In vitro free radical scavenging activity of methanol extract of the leaves of Mimusops elengi linn. Bangl J Vet Med 2008;6:197-202.
9. http://www.ayushveda.com/herbs/coriandrum-sativum.htm [Last accessed on 16 Feb 2017]

10. http://www.coriandrumsativum.com/coriandrum-sativummedical-uses/ [Last accessed on 16 Feb 2017]

11. Bogavac M, Karaman M, Janjušević L, Sudji J, Radovanović B, Novaković $\mathrm{Z}$, et al. Alternative treatment of vaginal infections in vitro antimicrobial and toxic effects of Coriandrum sativum $L$. and Thymus vulgaris L. essential oils. J Appl Microbiol 2015;119:697-710.

12. Mani V, Parle M, Ramasamy K, Abdul Majeed AB. Reversal of memory deficits by Coriandrum sativum leaves in mice. J Sci Food Agric 2011;91:186-92.

13. Harsha SN, Anilakumar KR. In vitro free radical scavenging and DNA damage protective property of Coriandrum sativum L. leaves extract. J Food Sci Technol 2014;51:1533-9.

14. Reddy LH, Jalli RD, Jose B, Gopu S. Evaluation of antibacterial and DPPH radical scavenging activities of the leaf extracts and essential oil of Coriandrum sativum Linn. World J Pharm Res 2012;1:705-16.

15. Mandal S, Mandal M. Coriander (Coriandrum sativum L.) essential oil: Chemistry and biological activity. Asian Pacific J Trop Biomed 2015;5:421-8.

16. Kuganathan N, Saminathan S, Muttukrishna S. Toxicity of Datura alba leaf extract to aphids and ants. Int J Toxicol 2008;5:1-6.

17. Shrivastava S, Leelavathi S. Preliminary phytochemical evaluation of leaf extracts of Catunaregum spinosa Thunb. Int J Pharm Sci Rev Res 2010;3:114-8.

18. Paul S, Ghosh D, Ghosh AK, Dey M, Chattopadhyay A, Bandyopadhyay D. Lead induces oxidative stress in rat heart and liver tissue homogenates: an in vitro study. J Cell Tissue Res 2013;13:3829-37.

19. Ghosh D, Paul S, Naaz S, Bhowmik D , Dutta M, Ghosh AK, Firdaus SB, Chattopadhyay A, Reiter RJ, Bandyopadhyay D. Melatonin protects against lead acetate induced oxidative stress-mediated changes in morphology and metabolic status in rat red blood cells: a flow cytometric and biochemical analysis. J Pharm Res 2016;10(6):381-402.

20. Buege JA, Aust SG. Microsomal lipid peroxidation. Methods Enzymol 1978;52:302-10. 
21. Beers Jr RF, Sizer IW. A spectrophotometric method for measuring the breakdown of hydrogen peroxide by catalase. J Biol Chem 1952;195:133-40.

22. Mitra E, Ghosh AK, Ghosh D, Mukherjee D, Chattopadhyay A, Dutta $\mathrm{S}$, et al. Protective effect of aqueous curry leaf (Murraya koenigii) extract against cadmium-induced oxidative stress in rat heart. Food Chem Toxicol 2012;50:1340-53.

23. Lowry $\mathrm{OH}$, Rosebrough NJ, Farr AL, Randall RJ. Protein measurement with the Folin phenol reagent. J Biol Chem 1951;193:265-75

24. Kang J, Chen Y, Epstein PN. Suppression of doxorubicin cardiotoxicity by overexpression of catalase in the heart of transgenic mice. J Biol Chem 1996;271:12610-6.

25. Kirshenbaum LA, Singal PK. Increase in endogenous antioxidant enzymes protects hearts against reperfusion injury. Am J Physiol 1993;265:H484-93

26. Ramchandani S, Das M, Joshi A, Khanna SK. Effect of oral and parenteral administration of metanil yellow on some hepatic and intestinal biochemical parameters. J Appl Toxicol 1997;17:85-91.

27. Chaudhary KR, Batchu SN, Seubert JM. Cytochrome P450 enzymes and the heart. IUBMB Life 2009;61:954-60.

28. Saravanan G, Prakash J. Effect of garlic (Allium sativum) on lipid peroxidation in experimental myocardial infarction in rats. J Ethnopharmacol 2004;94:155-8.

29. Blokha VV, Kagan VY, Sitkovskii MV, Danilov VS, Kols OR Koslov YP. Peroxidation of lipids and conduction of excitation in frog muscles. Biofizika 1972;17:549-51.

30. Janero DR1, Hreniuk D, Sharif HM. Hydrogen peroxide-induced oxidative stress to the mammalian heart muscle cell (cardiomyocyte): lethal peroxidative membrane injury. J Cell Physiol 1991; 149:347-64.

31. Priscilla DH, Prince PSM. Cardioprotective effect of gallic acid on cardiac troponin-T, cardiac marker enzymes, lipid peroxidation products and antioxidants in experimentally induced myocardial infarction in Wistar rats. Chem Biol Interact 2009;179:118-24.

32. Nirmala C, Puvanakrishnan R. Effect of curcumin on certain lysosomal hydrolases in isoproterenol-induced myocardial infarction in rats. Biochem Pharmacol 1996;51:47-51.

33. Susila R, Jeeva Gladys R, Balagurusamy K, Mubarak A. Review of siddha cardiology and cardioprotective herbs. Int J Herbal Med 2013;1:71-5.

34. Babu BH, Shylesh BS, Padikkala J. Antioxidant and hepatoprotective effect of acanthus ilicifolius. Fitoterapia 2001; 72:272-7.

35. Prior RL, Cao GH, Martin A, Sofic E, McEwen J, O’Brien C, et al. Antioxidant capacity as influenced by total phenolics and anthocyanin content, maturity, and a variety of Vaccinium species. J Agric Food Chem 1998;46:2686-93.

36. Braughler JM, Duncan CA, Chase LR. The involvement of iron in lipid peroxidation. Importance of ferrous to the ferric ratio in initiation. J Biol Chem 1986;261:10282-9.

37. Morelli R, Russo-Volpe S, Bruno N, Scalzo RL. Fentondependent damage to carbohydrates: free radical scavenging activity of some simple sugars. J Agric Food Chem 2003;51:7418-25.

38. Mitra E, Ghosh D, Ghosh AK, Basu A, Chattopadhyay A, Pattari $\mathrm{SK}$, et al. Aqueous tulsi leaf (Ocimum sanctum) extract possesses antioxidant properties and protects against cadmium-induced oxidative stress in rat heart. Int J Pharm Pharm Sci 2014;6:500-13.

\section{How to cite this article}

- $\quad$ Rabindra Nath Dome, Sanjib Hazra, Debosree Ghosh, Suvendu Ghosh. Beneficial effects of ethanolic leaf extract of Coriandrum sativum on metanil yellow induced alteration in activity of catalase and level of lipid peroxidation in hercine cardiac tissue in vitro. Int J Pharm Pharm Sci 2017;9(5):203-209. 